\title{
PSALAMSKO TROJSTVO - NASTANAK I IKONOGRAFSKO-TEOLOŠKI RAZVOJ OD PSALTIRSKE ILUSTRACIJE DO TRINITARNOG IKONOGRAFSKOG TIPA
}

Iako u Starom zavjetu nema izravne objave Božje trojstvenosti, kršćani su tipološkim čitanjem u mnogim starozavjetnim tekstovima prepoznavali proročke ukaze na Isusa Krista i njegovu objavu Boga kao Oca, Sina i Duha Svetoga. Ovakva je kršćanska interpretacija razumljivo opečatila i rukopisne ilustracije koje su kroz mnoga stoljeća u različitim izdanjima pratile starozavjetne tekstove. $U$ ovom se radu predstavlja i istražuje jedna takva ilustracija. Riječ je o tzv. Psalamskom Trojstvu, ilustraciji prvoga retka Psalma 110. (109.) čiji je ikonografski i interpretativni razvoj spregnut s promjenama teološkog razumijevanja značenja tog psalamskog retka (ponajprije u svjetlu postupne kristologizacije psaltira) i kristološko-trinitarnog sadržaja koji je bitna sastavnica temelja kršćanske vjere. Spomenuta psaltirska ilustracija (koja je vrhunac aktualnosti doživjela u 13. stoljeću) u prvom razdoblju svoga razvoja ikonografski jasno odražava binitetnu (dvojstvenu) sliku Boga, no postupno značajno mijenja svoja sadržajna i interpretativna svojstva te, kao Trojstvo u slavi postaje dominantan trinitaran ikonografski tip kršćanskoga Zapada, posebno u vrijeme Tridentskoga koncila i katoličke obnove. U svom glavnom dijelu rad analizira složenu ikonografsko-teološku pozadinu procesa koji stoji iza razvoja psaltirske ilustracije Psalamsko Trojstvo u ikonografski tip Trojstvo u slavi. Naglašava se kako je u okviru toga razvoja sadržajni naglasak (u smislu poimanja slike Boga) najprije kristološki a onda trinitarani, te da se u psaltirskoj ilustraciji Psalamsko Trojstvo prepoznaje prvi cjeloviti prikaz kršćanske slike Boga kao Trojstva i najraniji antropomorfni prikaz Boga Oca.

Ključne riječi: Psalam 110. (109.), Trojstvo, psaltir, ikonografija

\section{UVOD}

Među ilustriranim rukopisima srednjega vijeka, psaltir zasigurno zauzima istaknuto mjesto. Pri tom su iz teološko-ikonografske perspektive osobito zanimljive psaltirske ilustracije ranoga i razvijenog srednjeg vijeka. Njihova je dragocjenost tim veća što su značajno utjecale na razvoj kasnijih knjiž- 
nih ilustracija i stvaranje ikonografskih tipova. Predmet je ovoga istraživanja psaltirska ilustracija Psalma 110. (109.), ${ }^{1}$ točnije njegova prvog retka, koja je poznata pod nazivom Psalamsko Trojstvo, a na osnovi koje je kasnije nastao ikonografski tip Trojstvo u slavi. ${ }^{2}$

Svrha je ovog rada navesti i istražiti najranije poznate slikovne prikaze Ps 110,1, potom ustanoviti ikonografski razvoj ove ilustracije s naglaskom na prijelaz s binitetne na trinitarnu ikonografiju, istražiti tipologiju slikovnog prikaza tog psalamskog retka kao i uzajamnu povezanost te tipologije s psalamskim tekstom kojega prikaz oslikava i tumači. Glavni je naglasak istraživanja na složenosti ikonografsko-teološkog sadržaja ilustracije Ps 110,1 i to stoga što je Psalamsko Trojstvo prvi cjeloviti slikovni prikaz kršćanske slike Boga kao Trojstva i prvi antropomorfni prikaz Boga Oca. Pokazat ćemo da se slikovni prikaz kršćanskoga poimanja Boga kroz ilustraciju Ps 110,1 razvijao po uzoru na teološko-dogmatski put od kristološkog i pneumatološkog do trinitarnog sadržaja, ali i kao potvrda toga sadržaja.

Na početku donosimo kršćanske argumente u preuzimanju starozavjetne Knjige psalama, odnosno kristološko tumačenje njezina sadržaja, posebno Ps 110,1 , na kojemu se zasniva i ikonografski sadržaj koji istražujemo.

\section{PSALTIR KAO KRŠĆANSKA MOLITVENA KNJIGA}

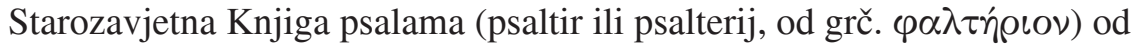
samog je početka u kršćanstvu prihvaćena kao prikladan molitveni i liturgijski sadržaj, te je kao tzv. molitvenik Izraela vrlo rano postala i istinski molitvenik Crkve, što će se očitovati i kroz stoljeća sačuvati u liturgijskoj molitvi časova, koja se i temelji na židovskoj molitvenoj praksi razdijeljenosti dana na sate. ${ }^{3}$

\subsection{Kristologizacija psaltira}

Prvi razlog preuzimanja psaltira kao kršćanske molitve nasljedovanje je molitvene prakse Isusa i njegovih učenika, koji su, kao Židovi u sinagogi i

1 Zbog različitog brojenja psalama (ovisno o tomu broji li se prema grčkoj ili hebrejskoj varijanti) na mnogim se mjestima u literaturi, osobito starijoj, može naći podatak da se radi o Psalmu 109.

2 Postoji više ikonografskih tipova Presvetoga Trojstva: simbolički, alegorijski, različiti antropomorfni prikazi. Među antropomorfnim se tipovima prepoznaju primjerice: Prijestolje milosti, zatim Paternitas ili Očinstvo (tj. lik Oca kao starca koji dominira slikom, a u krilu drži Sina u obličju dječaka, dok je Duh Sveti simbolički prikazan likom goluba), tzv. tricephali (različiti prikazi jednog tijela s tri glave ili jedne glave s tri lica), a među njima posebno važno mjesto u zapadnoj ikonografiji zauzima tip Trojstvo u slavi. Više o tomu u PEHAR 2016: 139-236.

3 Usp. ZAGORAC 1996: 241-274. 
hramu prakticirali uobičajenu molitvu psalama. Drugi, važniji razlog leži u kršćanskom tumačenju psalama. Crkva ih je od početka tumačila alegorijski i tipološki, dakle shvaćala ih je kao proročki govor, kao nadahnutu riječ, u vjeri da je njezin puni sadržaj usmjeren na Isusov život i ispunjen u otajstvima njegova života, te da upravo odatle crpi svoje najdublje i neprolazno značenje. ${ }^{4}$ Ovime kršćansko tumačenje samo potvrđuje već u ranom židovstvu prisutnu sklonost oblikovanju tipova, prema kojoj se ni Davida kao autora većine psalama nije promatralo samo kao kralja koji je u psalmima opjevao osobno proživljavanje napastovanja, trpljenja i spasenja, nego kao paradigmatski lik svakog Izraelca i čitavog izraelskog naroda. Kasnijom preobrazbom Davidova lika u lik proroka, Davidu pripisane psalamske riječi tumačene su kao mesijanska proroštva. Ovo se ponajprije odnosi na Ps 2., 72. i 110. ${ }^{5}$

Budući da su kršćani u Kristu prepoznali obećanog Mesiju, Davidova su proroštva od početka primjenjivali na Kristovo vrijeme i osobu, te su s takvim razumijevanjem od početka prihvaćali i psalme kao svoju temeljnu molitvu. Kršćansko prisvajanje psaltira kao vlastite molitve očitovalo se i u doksologiji Slava Ocu i Sinu i Duhu Svetomu koja je dodavana kao završetak svakog psalma i kojom se psaltiru davao izrazit kršćanski pečat, odnosno kristološko-trinitarno značenje. Kršćansko prihvaćanje psaltira odvija se dakle u procesu tzv. kristologizacije psaltira.

Pojam kristologizacija psaltira odnosi se na pripisivanje Kristu uzvišenih naslova i mesijanske časti na koju upućuju riječi psalama, prije svega prenošenje na Krista naslova Gospodin - Kyrios (grč. xú oznaka božanskog dostojanstva. Postupci se kristologizacije psaltira temelje kako na eksplicitnim novozavjetnim citatima psalama i njihovom tumačenju, prema kojemu je i sam Krist sadržaje psalama primjenjivao na sebe, tako i na ranokršćanskoj otačkoj egzegezi psalamskih tekstova.

\subsection{Kristološko-trinitarni sadržaji Ps 2,7 i 110,1}

Iz perspektive kristološko-trinitarnog sadržaja, u najranije vrijeme primarno svedenog na odnos Oca i Sina, posebno su bili zanimljivi psalmi 2. i 110. Dva su mjesta iz ovih psalama kršćani prepoznavali kao izričit govor o božanskim osobama Oca i Sina: »Gospodin mi reče: Ti si sin moj, danas te rodih «, lat. Dominus dixit ad me: Filius meus es tu: ego hodie genui te (Ps 2,7) te »Reče Gospodin Gospodinu mojemu: 'Sjedi mi zdesna dok ne položim

\footnotetext{
4 Usp. JÖRG AUF DER MAUR 2009: 695-696 i HÄUSSLING 2009: 696-698.

5 Usp. HOSSFELD 2009: 689-693.
} 
dušmane za podnožje tvojim nogama!' « lat. Dixit Dominus Domino meo: Sede ad dextris meis, donec ponam inimicos tuos scabellum pedum tuorum (Ps 110,1). ${ }^{6}$

Najranije novozavjetno tumačenje ovih psalamskih mjesta nalazimo u Poslanici Hebrejima. Ondje se upravo navedenim redcima kršćanima iz židovstva argumentira Kristovo uzvišeno bogosinovstvo, prepoznajući da je Kristov značaj izvrsniji od onog nebeskih anđela: »Zbilja, komu od anđela ikada reče: 'Ti si sin moj, danas te rodih'? I još: 'Ja ću mu biti Otac, a on će mi biti Sin.' [...] A upravi li na kojega od anđela riječi: 'Sjedi mi s desne dok ne postavim neprijatelje tvoje podnožjem nogama tvojim?' «(Heb 1,5.13). Kristovo se bogosinovstvo dovodi u vezu s psalamskim obećanjem osobitoga svećeništva koje se također primjenjuje na Krista: »Tako ni Krist nije sam sebi dodijelio velikosvećeničku čast, nego onaj koji mu upravi riječi: 'Ti si Sin moj, ja te danas rodih', kao što i na drugome mjestu veli: 'Ti si svećenik zauvijek, sličan Melkisedeku'. On, pošto u vrijeme svog zemaljskog života prikaza molitve i prošnje s jakim vapajima i sa suzama onomu koji ga je mogao spasiti od smrti, bijaše uslišan zbog strahopoštovanja. I premda je bio Sin, iskustveno nauči poslušnost od onoga što je pretrpio te postigavši savršenstvo postade svima koji mu se pokoravaju uzrok vječnoga spasenja, on koga je Bog proglasio velikim svećenikom sličnim Melkisedeku. «(Heb 5,5-8). U 7. se poglavlju iste poslanice upravo tim osobitim svećeništvom primijenjenim na Krista još jednom detaljno obrazlaže Kristova posebnost koja je posebnost njegova sinovskog odnosa s Bogom. »Pa da je savršenstvo bilo ostvareno levitskim svećeništvom - izabrani je naime narod primio Zakon u uskoj povezanosti s njime - kakva bi bila još potreba da ustaje drugog roda svećenik, 'sličan Melkisedeku', o kome se ne bi moglo kazati da je sličan Aronu? Ako se, naime, mijenja svećeništvo, nužno se mijenja i Zakon. Uistinu onaj za koga se ovo veli pripada drugom plemenu, od kojega nitko nije imao posla sa žrtvenikom. Bjelodano je, naime, da je naš Gospodin izišao iz Judina plemena, za koje Mojsije govoreći o svećenicima ništa ne reče. I to biva kudikamo očitije ako ustaje drugog roda svećenik koji je sličan Melkisedeku, koji nije postao svećenikom po zakonu rodbinskog nasljedstva, već po snazi vječnog života. Zbilja svjedočanstvo o njemu glasi: 'Ti si svećenik zauvijek, sličan Melkisedeku.' Tim se ukida prijašnja zapovijed zbog njezine nemoći i beskorisnosti - budući da Zakon ništa nije priveo k savršenstvu - a uvodi se bolja nada koja nas približuje Bogu. Nadalje, ukoliko se ovo nije dogodilo bez zakletve - drugi su, naime, bez zakletve postali svećenicima, a ovaj sa zakletvom onoga koji na nj upravi riječi: 'Zakle se Gospodin i neće

${ }^{6}$ U Novom je zavjetu Ps 110,1 najcitiraniji starozavjetni redak. Usp. DAUTZENBERG 1995: 63. 
opovrći: ti si svećenik zauvijek' - utoliko je Isus postao jamac boljega Saveza.« (Heb 7,11-22).

U sinoptičkim evanđeljima sam Isus u raspravi sa Židovima citira Ps 110. Priznajući mu Davidovo autorstvo i nadahnuće Duhom Svetim, primjenjuje ga na sebe. »Kad se skupe farizeji, zapita ih Isus: 'Što mislite o Kristu? Čiji je on sin?' 'Davidov', odgovore mu. Reče im: 'Kako ga onda David, potaknut od Duha, naziva Gospodinom, kad kaže: Reče Gospodin Gospodinu mome: Sjedi mi s desne strane dok ne položim tvoje neprijatelje pod noge tvoje?' $\mathrm{Pa}$ ako ga David zbilja naziva Gospodinom, kako mu može biti sin?« (Mt $22,41-45)^{7}$

I apostol Petar u svom obraćanju Židovima na Pedesetnicu, između ostalih Davidovih proroštava, koristi i Ps 110 argumentirajući da su mesijanska obećanja tog psalma ispunila u Kristu. Opisuje to Luka u Djelima apostolskim: »Njega je, to jest Isusa, Bog uskrisio. Tome smo mi svjedoci. On, sad uzvišen Božjom desnicom, pošto je od Oca primio obećanog Duha Svetoga, izlio je ovo što sami i vidite i čujete. Dakako, David nije uzašao na nebo; ta sam kaže: 'Reče Gospodin Gospodinu mome: Sjedi mi s desne strane, dok ne učinim tvoje neprijatelje podnožjem nogama tvojim!' Dakle: neka sav dom Izraelov sa sigurnošću spozna da je Bog učinio i Gospodinom i Mesijom tog Isusa koga ste vi razapeli!« (Dj 2,32-36). O Kristovu uzvišenju i njegovu smještaju zdesna Bogu koje je stekao smrću i uskrsnućem svjedoči i Poslanica Rimljanima 8,34 u kontekstu govora o opravdanju Božjih izabranika: »Tko će ih osuditi? Isus Krist koji je umro - još bolje: koji je uskrsnuo - koji je s desne strane Bogu i koji posreduje za nas? «. Kristov je jedinstven smještaj kršćanima, dakle, važan zbog njegova zauzimanja za nas, te se povezuje s jedinstvenošću njegove svećeničke službe (usp. Ps 110,4). Isusa se ovdje, jednako kao i u Poslanici Hebrejima, promatra kao eshatološkog velikog svećenika, a njegovu žrtvu kao posredovanje u konačnom izmirenju čovjeka s Bogom. Riječ je o ranijoj velikosvećeničkoj kristologiji, prema kojoj Krist kroz smrt i uskrsnuće stječe bogosinovstvo i ulazi u vječno svetište na nebu. No, ubrzo će, kao i u navedenoj usporedbi s anđelima, ovo funkcionalno tumačenje sinovstva prijeći u shvaćanje sinovstva u ontološkoj preegzistenciji. ${ }^{8}$

S Isusovim iznimnim uzvišenjem povezana je i njegova pobjeda nad svim neprijateljima i njihovo podlaganje pod noge uzvišenog Krista, o čemu se govori na kraju retka Heb 110,1. Time se još jednom ističe kako Isus ima božansku vlast i da je na jedinstven način blizak Bogu, tj. identificira ga se

\footnotetext{
7 Vidi paralelna mjesta: Mk 12,36 i Lk 20, 41-44. (Kurziv u tekstu citata M. P.)

8 Usp. CIFRAK 2007: 454, 457.
} 
kao Božjeg Sina. Iz svega je razumljivo da se često novozavjetno citiranje navedenih psalamskih redaka, posebno Ps 110., kojemu je polazište uskrsna vjera da je Bog raspetog Krista od mrtvih uskrisio i uzvisio u nebesku slavu, najčešće koristi upravo u svrhu argumentiranja Isusova vječnog bogosinovstva, a kao takvo će poslužiti i kasnije u ranim otačkim kristološkotrinitarnim raspravama, ponajprije onima s arijancima. Dok su arijanci Ps 110 tumačili naglašavajući diferencijaciju položaja Oca i Sina te ga držali argumentom u korist subordinacije, otačka ga je teologija u pravilu tumačila u smislu novozavjetnog mesijanskog ukaza i priznanja Isusove božanske časti te ga koristila kao argument protiv arijanaca. Iako je među Ocima i ranim teolozima bilo i »onih koji ga, poput sv. Jeronima, nisu tumačili trinitarno, nego su zastupali mišljenje da riječi 'reče Gospodin Gospodinu mojemu' božanski vječni Krist upućuje utjelovljenom Kristu na zemlji (PEHAR 2016: 213), ${ }^{9}$ s vremenom je kristološko-trinitarno tumačenje ovoga psalma prevladalo i postalo dominantno.

Tako su, tumačeni upravo pod ovim vidom odnosa Krista i njegova nebeskog Oca, oba navedena psalamska retka već vrlo rano postala zanimljiva i izazovna za ilustriranje. Pri tom je osobito zanimljiv bio Ps 110,1 koji je zbog navedenog kristološko-trinitarnog tumačenja kao ukaza na središnje otajstvo kršćanske vjere, zaokupljao iznimnu pažnju ${ }^{10}$ te je stekao istaknuto i povlašteno mjesto unutar brevijara - naime njime počinje časoslovna molitva nedjeljne Večernje.

\section{PSALTIRSKE ILUSTRACIJE}

Među ilustriranim rukopisima srednjega vijeka, psaltir zbog svojih bogatih ilustracija zauzima veoma važno mjesto. Pri tom su iz teološko-ikonografske perspektive osobito zanimljive psaltirske ilustracije ranoga (5. - 11. stoljeće) i razvijenog (12. - 13. stoljeće) srednjeg vijeka, a kraj 12. i 13. stoljeća smatraju se vremenom procvata psaltirske ilustracije. ${ }^{11}$ Slikovni su prikazi

\footnotetext{
${ }^{9}$ Više o tome v. KANTOROWICZ 1947: 76.

${ }^{10}$ Zanimljivo je da su prikazi Ps 2., u kojemu je kršćanska tradicija, kako je već spomenuto, također prepoznavala ukaz na trojstvenu sliku Boga, dosta rijetki i nisu razvili jednu kompaktnu slikovnu tradiciju. Usp. BRAUENFELS 1954: XXVI.

${ }^{11}$ Usp. BÜTTNER 2004: 4. Uzroke ovakvoga razvoja Büttner prepoznaje prije svega u ondašnjoj emancipaciji laika, kojima u 12. i 13. stoljeću postaje sve pristupačnije sudjelovanje u naobrazbi, osobito onoj duhovnoj. Umijeće čitanja i pisanja postaje sve raširenije, čime raste i interes za literaturu, posebno religiozne tekstove. Među njima psaltir, kao molitvenik koji sada u ruci mogu imati i laici (iako u početku samo oni iz viših staleža), zasigurno je zauzimao prvorazredno mjesto.
} 
psaltirskog teksta vrlo vjerno oslikavali teološka strujanja tog vremena, jer je na njih bilo prenošeno kako tadašnje teološko tumačenje samih psalama, tako i cjelina kršćanskog teološkog nauka i življena vjera onoga vremena. Osim ilustracija koje su bile u izravnoj povezanosti s većim ili manjim dijelovima psaltirskoga teksta, teološki su posebno zanimljivi oni slikovni prikazi koji su, obično kao naslovne slike ili historizirani inicijali, pokušavali općenito povezati starozavjetne sadržaje s novozavjetnim događajima ili s kršćanskim poimanjem spasenja. ${ }^{12}$ Psaltirski su tekst i slika tako sadržajno i svrhom ponekad ostajali na različitim razinama: na razini teksta psalam je bio molitva hvale i zahvaljivanja Bogu, dok je popratna ilustracija prikazivala kršćansko razumijevanje spasenja. Ilustracije su tako uz svoju estetsku funkciju služile i kao poticaj na soteriološki usmjerenu pobožnost i teološki i dogmatski utemeljeno kršćansko promišljanje.

Psaltirske su ilustracije 12. i 13. stoljeća dragocjene i zbog toga što su svojim formiranim slikovnim tipovima u nekoliko nadolazećih stoljeća služile kao stabilni predlošci za izradu drugih knjižnih iluminacija i minijatura, a nerijetko su postajale i predlošci za stvaranje kasnijih ikonografskih tipova u zapadnom slikarstvu. Ovo se osobito pokazuje na ilustracijama koje su praktički postajale standardna oprema svakog psaltira. Naime, budući da su psaltiri u ovom vremenu postajali sve više raskošno uređena izdanja molitvenika koji nisu smjeli izostajati u rukama uglednika, formatom su postajali sve manji. Zbog smanjenoga je formata psaltirske knjige postajalo gotovo nemoguće ilustrirati svaki psalam, tako da su ilustracije takvih luksuznih izdanja bile pridržane samo za one stranice i tekstove koji su držani najvažnijima. Tako su se ilustracije uglavnom nalazile uz psalme koji se mole na početku Jutarnje ili nedjeljne Večernje, te uz svaki od osam psalama kojima počinje osam dijelova svakodnevne liturgijske molitve (Ps 1, 26, 38, 52, 68, 80, 97 i

\footnotetext{
${ }^{12}$ Forma ilustracije uvelike je ovisila o postojećoj razdiobi psaltira. Tako je u Italiji i Francuskoj prevladavala osmodijelna struktura (istaknuti su psalmi Večernje kojima počinje dnevna liturgija), dok je u Engleskoj i Njemačkoj početna trodijelna struktura psaltira vremenom postala osmodijelnu, desetodijelna ili koja kombinacija postojećih razdjelbi psaltirskoga teksta. Ilustracije su se već prema tomu odnosile na konkretne riječi psalma ili su bile naslovne slike koje su oslikavale kršćansko shvaćanje cjelovitog teksta psaltira. Ipak se i unatoč ovoj formalnoj određenosti kao uvjetu ilustrativnoga sadržaja mogu primjerice u anglosaksonskoj umjetnosti vrlo rano (kraj 10. i 11. stoljeće) naći brojni primjeri rubnih ilustracija koje se odnose na izravno shvaćanje psalamskih riječi. Tako da se anglosaksonsko područje smatra domovinom doslovnog tumačenja psalamskoga teksta i na riječi izravno usmjerene psalamske ilustracije. Engleska će se psaltirska ilustracija tek tijekom 12. stoljeća okrenuti povijesnoj ilustraciji koja će u sljedećim stoljećima dominirati ovim područjem. Uz ovo formalno razlikovanje psaltira treba svakako imati u vidu i razlike između (bogatije ilustriranog) rimskog i (sporadično ilustriranog) monastičkoga psaltira. Usp. BÜTTNER 2004: 2-4,12-32.
} 
110). ${ }^{13}$ Budući da je Ps 110 otvarao molitvu nedjeljne Večernje, već je time pripadao skupini istaknutih psalama, a njegovom je značaju svakako doprinosila teološka težina njegova sadržaja. Stoga su i njegove ilustracije gotovo neizostavne u većini psaltirskih izdanja, a njihov će se razvoj ovdje pobliže promotriti upravo iz ikonografsko-teološke perspektive.

\section{ILUSTRIRANJE PS. 110. - POVIJESNI RAZVOJ I IKONOGRAFSKI SADRŽAJ}

Iako se, poglavito u najranijim psaltirima, među ilustracijama Ps 110 mogu naći prikazi: Davida kao starozavjetnog proroka koji navješćuje Krista, ${ }^{14}$ Marijina krunjenja ili krunjenja Crkve od strane Krista, svetaca, ${ }^{15}$ pa čak i prikazi Posljednjeg suda (uz završne retke ovoga psalma koji upućuju na Kristovu eshatološku pobjedu), ${ }^{16}$ ilustratori su se vrlo rano i gotovo isključivo usredotočili na prvi redak toga psalma, oslikavajući ga u skladu s tipološkim tumačenjem njegova sadržaja prema kojemu se on odnosi na Kristovo uzvišenje i proslavu. Tako neke najranije ilustracije ovoga retka prikazuju samo Krista na nebeskom prijestolju ili njegovo uskrsnuće koje se već shvaća kao uzdignuće u slavu. ${ }^{17}$ Nakon ovakvih tipološki motiviranih prikaza Krista vrlo se brzo susreću ilustracije na kojima su zajedno likovi Oca i Sina, s tim da je Otac prikazan kao nositelj glavne uloge u događaju Sinova uzdignuća i nebeske proslave, što se redovito signalizira smještanjem lika Oca na viši položaj unutar kompozicije (u odnosu na smještaj lika Sina koji se nalazi niže od Oca) ili specifičnim položajem Očeve ruke.

Ikonografija ilustracije Ps 110,1 i tekst toga retka redovito su u dvosmjernom odnosu: ikonografija ilustracije slijedi (teološko) tumačenje i (opće) kršćansko razumijevanje njegova teksta te istodobno uzvratno služi kao slikovni doprinos razvoju tog istog tumačenja i razumijevanja teksta kojeg ilustrira.

\footnotetext{
${ }^{13}$ Usp. BÜTTNER 2004: 5-6. ROWICZ 1947: 75.

${ }^{15}$ Usp. HASELOFF 1938: 101-123.

${ }^{16}$ Usp. BÜTTNER 2004: 33.

${ }^{17}$ Usp. HASELOFF 1938: 101-123.
}

${ }^{14}$ Razumljivo je da neke ilustracije Davida likom starozavjetnog proroka koji navješćuje Krista prikazuju Davidovo uzdignuće u nebesku slavu. Također, nije neobično da su Krist i David lako zamjenjivi, jer je i David u kršćanstvu smatran prefiguracijom Krista. Sveti je Jeronim u traktatu o Knjizi psalama pisao: »Qui filius Dei est, ipse et filius David est «(Onaj koji je Sin Božji, isto je tako sin Davidov), a slično je odnos Krista i Davida tumačio i sveti Augustin: »Filius David secundum carnem, dominus David secundum divinitatem « (Sin je Davidov po tijelu, a Gospodin Davidov po božanstvu). Latinski navodi prema: KANTO- 
Vremenom se iz te ilustracije razvio prikaz koji će gotovo bez iznimke donositi dragocjeni prikaz kršćanske slike Boga kao Trojstva. ${ }^{18}$ Upravo će takva ikonografija pridavati ovomu psalmu neusporedivu važnost u odnosu na druge starozavjetne tekstove.

\subsection{Prikazi biniteta}

Sukladno kršćanskoj teologiji koja je sliku Boga u prvim stoljećima definirala polazeći od problematike i dogmatskog određenja odnosa Oca i Sina, najraniji su prikazi kršćanske slike Boga binitetni, a prikazuju uskrslog Krista i Boga Oca na nebeskom prijestolju. Teološka je pozadina tih prikaza proslava Sina koja se razumijevala kao djelo Oca: Bog Otac je taj koji svojom božanskom moći uskrisuje Sina te ga nakon muke i smrti uzdiže u proslavu postavljajući ga sebi zdesna. Tako razumijevanje Sinovljeve proslave pripada najranijim sadržajima kršćanske vjere.

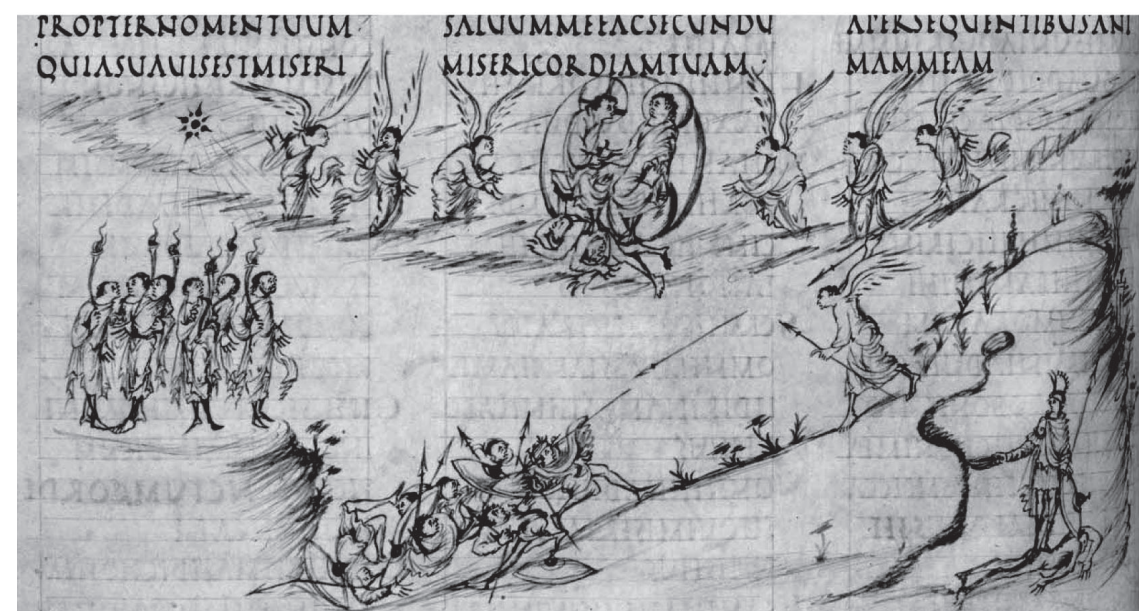

Slika 1. Utrechtski psaltir, Ilustracija Ps 110,1, f. 64v. (detalj) Izvor: Digitalizirana verzija psaltira u knjižnici Sveučilišta u Utrechtu: http://psalter.library.uu.nl/page?p=135\&res=2\&x=0\&y=113 (2.11.2019.)

Figure 1. Utrecht Psalter, Illustration Ps 110,1, f. 64v. (Detail) Source: A digitized version of the Psalter in the Library University Utrecht: http://psalter.library.uu.nl/page? $\mathrm{p}=135 \& \mathrm{res}=2 \& \mathrm{x}=0 \& \mathrm{y}=113$ (2.11.2019.)

Najstariji je prikaz Oca i Sina u intimnoj blizini i živom razgovoru iznad neprijatelja koji su prikazani pod njihovim nogama, kao ilustracija Ps 110.,

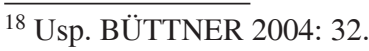


sačuvan u poznatom Utrechtskom psaltiru, remek djelu karolinške psaltirske ilustracije (Slika 1.). ${ }^{19}$ Iako je riječ o latinskom psaltiru, neka su istraživanja pokazala da se njegove ilustracije bolje razumiju kada se uzme u obzir grčki, a ne latinski psalamski tekst, što upućuje na činjenicu da su ilustratori tog psaltira predloške za svoje crteže pronalazili u starim bizantskim rukopisima. ${ }^{20}$ Ovakva uska povezanost s kasnoantičko-bizantskom umjetnošću dade se dokazati i u još nekim kasnijim zapadnim psaltirima, kakav je primjerice Stuttgartski psaltir iz 10. stoljeća. ${ }^{21}$ Stoga se može govoriti o skupini psaltira čije ilustracije većim dijelom vjerno oponašaju ilustracije Utrechtskog psaltira ili nekog izgubljenog paralelnog rukopisa (poput primjerice Harleyeva psaltira, ${ }^{22}$ Eadwineova psaltira, ${ }^{23}$ Anglo-katalonskog ili Pariškog psaltira ${ }^{24}$ ), kao i o rukopisima koji su neovisno od utrechtskog predloška ilustrirani po načelima srodne ilustracije i iz čijeg će se neposrednog utjecaja razviti slikovna shema francuskih psaltira 13. stoljeća. ${ }^{25}$ Podatak o povezanosti ovih zapadnih psaltira s bizantskim rukopisima dragocjen je jer upućuje na to da ilustracije psalama (ovdje se ne misli na naslovne slike) imaju teološku pozadinu, što znači da su one iskaz kršćanskoga razumijevanja određenog psalamskog teksta.

Upravo je u tom smislu osobito značajna ilustracija 110. psalma. Riječ je prije svega o oslikavanju već ranije vođenih (3. i 4. st.) ali u kasnijim stoljećima (8. - 12. st.) još uvijek živih i značajnih teoloških rasprava s arijancima

\footnotetext{
${ }^{19}$ Psaltir je izrađen oko 820.-835. godine u benediktinskom samostanu u Reimsu ili blizu njega. Radi se o rukopisu od neprocjenjivog značaja. Osobito je zanimljiv zbog 166 crteža tušem koji prate tekst svakog od 150 psalama i 16 dodanih biblijskih himana. Na ilustracijama je radilo osam umjetnika, ali je stil dosta ujednačen. Crteži su veoma rafinirani i kompleksni i pokazuju značajnu originalnost, inovativnost i iskorak u odnosu na slične ilustracije u istom ili prethodnom razdoblju. Psaltir je 2015. godine upisan i na UNESCO-v registar svjetske dokumentarne baštine. Od 1732. čuva se u knjižnici Sveučilišta Utrecht. Više o psaltiru na stranicama knjižnice: http://bc.library.uu.nl/utrecht-psalter.html. Ovo je jedan je od prvih rukopisa u cijelosti reproduciran u fotografskom faksimilu. Ponuđena je i digitalna verzija.

${ }^{20}$ Usp. GRAEVEN 1898.

${ }^{21}$ Psaltir je nastao najvjerojatnije u sjevernoj Francuskoj, ali se čuva u Öffentliche Bibliothek u Stuttgartu (f. 23), po čemu nosi ime.

${ }^{22}$ Harleyev je psaltir (London, British Library, B.M. Harley 603.) iz prve polovice 11. stoljeća. Knjiga je nepotpuna i završava sa Psalmom 143., a ilustracije su precrtane iz Utrechtskog psaltira.

${ }^{23}$ Eadwineov psaltir (Cambridge, Cambridge Trinity College, R.17.1.) iz oko 1320. godine. Ilustracije su nadahnute ilustracijama Utrechtskog psaltira, ali bogatije.

${ }^{24}$ Anglo-katalonski ili Pariški psaltir (Paris, Bibliothèque Nationale, Lat. 8840), vjerojatno s kraja 12. st., za predložak je imao Eadwineov psaltir i primjetan je utjecaj Utrechtskog psaltira.

${ }^{25}$ Usp. BÜTTNER 2004: 2-3.
} 
(ili njihovim neizravnim nasljedovateljima) u kojima se branilo Isusovo bogosinovstvo i istobitnost s Ocem, a koje su otvorile i najznačajnije opečatile teološko određenje kršćanske slike Boga kao Trojstva. ${ }^{26}$

Neki interpretatori prethodno prikazane ilustracije Utrechtskog psaltira (i iz nje izvedenih kasnijih ilustracija) u njoj vide Jeronimov utjecaj, tj. drže da ta ilustracija ne prikazuje Boga Oca i Boga Sina, nego dvije Isusove naravi, božansku i ljudsku. ${ }^{27}$ Ipak, vjerojatnije je da ilustracija prikazuje kršćansko tumačenje Ps 110,1 koje proizlazi već iz pouskrsne vjere te da je riječ o prikazu Isusove proslave, tj. Isusova uzdignuća u nebesku slavu koja Isusu pripada po naravnom sinovstvu (po istobitnosti s Bogom Ocem), a što se na ilustraciji prikazuje time što Bog Otac uzdiže Sina. Takav prikaz Očeve proslave Sina proizlazi iz temeljne kršćanske vjere u istobitnost Oca i Sina i dogmatskog definiranja tog nauka kao ishoda teoloških rasprava s arijanizmom. ${ }^{28} \mathrm{Da}$ takve ilustracije aludiraju na crkveni nauk definiran kroz borbe $s$ arijanizmom, upućuju i prikazi neprijatelja pod nogama Oca i Sina. Ponekad je prikazan samo Lucifer kao prvi i najveći čovjekov neprijatelj, otac laži i zavodnik na krivi nauk, ali nerijetko su tu i Juda i Arije (što je vidljivo po sekundarnim obilježjima ili natpisima uz pojedine likove na ilustracijama). Juda je smatran neprijateljem kršćanstva zbog povijesne izdaje Isusa, a Arije je zbog svoga nijekanja Isusova božanstva izjednačavan s Judom, te su njih dvojica zbog svoga pogrešnog stava prema Isusovu božanstvu, smatrani najvećim neprijateljima Kristovim i onih koji su Kristovi i izjednačavani sa samim Luciferom.

Veliki je značaj ilustracija Ps 110,1 i u tome što su one najraniji izravni antropomorfni prikazi Boga Oca. Pod utjecajem starozavjetnog shvaćanja slike Boga, ali i zbog kršćanskog ustrajavanja na otajstvenosti Božjega bića te činjenice da se Bog Otac nije utjelovio niti se ljudima ikada objavio

\footnotetext{
${ }^{26} \mathrm{U}$ osporavanju arijanizma i njegova ontološkog subordinacionizma, otačka je teologija, kojoj u temelju stoji teologija velikih Kapadočana, pomogla razjasniti i dogmatski definirati kršćansku vjeru u istobitnost (homoousia) Sina s Ocem (na Nicejskom koncilu 325. godine), iako su elementi arijanizma još duga stoljeća nakon toga ostali značajan problem kršćanstva. Kasnije će se (na Carigradskom koncilu 381. godine) u raspravi s onima koji su nijekali boštvo Duha Svetoga dovršiti stvaranje kršćanskoga creda dogmatskim definiranjem božanske časti, a time i božanske naravi Duha Svetoga, čime je dogmatski izrečen i formalno dovršen kršćanski nauk o jednomu Bogu u trojstvu osoba.

${ }^{27}$ Usp. BRAUENFELS 1954: XXVI (autor se poziva na Jeronimovo djelo Breviarium in Psalmo, u PL 26, 1163).

${ }^{28}$ Riječ je o Nicejskom saboru iz 325. godine, na kojemu je potvrđena i definirana kršćanska vjera u Isusovo vječno bogosinovstvo, odnosno njegovu istobitnost s Ocem. Usp. DENZINGER; HÜNERMANN 2002: br. 125-126.
} 
u vidljivom obličju, kršćanstvo je dosta dugo zaziralo od izravnih prikaza Boga Oca. Primjereni su bili samo znakovni i simbolički prikazi, tj. Boga Oca se simboliziralo prikazom ruke, nebeskoga trona (grč. $\varepsilon \tau o \iota \mu \alpha \sigma i \alpha)$, trokuta, oka... ${ }^{29}$ Može se, dakle, reći da su upravo anglosaksonski iluminatori (iluminatori Utrechtskog psaltira) bili među prvim umjetnicima Zapada koji su Boga Oca prikazivali antropomorfno i to upravo ilustracijama Ps $110,1 .^{30}$

Otac i Sin na nekim su ilustracijama prikazani kao identični likovi, dok neki prikazi ipak ističu njihovu razliku u dobi, pa se Sina prikazuje kao mlađega muškarca, a Oca kao starca. Na nekim su ilustracijama njihovi likovi prikazani u istoj razini, dok je na nekima Sin prikazan niže od Oca. Sttutgartski psaltir donosi čak prikaz Oca i Sina na dva odvojena prijestolja što može upućivati na subordinaciju, ali i jednostavno na unutarnju dinamiku prikazanoga, tj. na čin uzvišenja Sina i njegova uvođenja u nebesku slavu kao djelo Oca koji Sina privlači k sebi, u svoju slavu. U tom su kontekstu zanimljive primjerice ilustracije koje prikazuju Oca kako pridržava Sina za ruku (zapešće) ili njegovu ruku stavlja na svoje koljeno. ${ }^{31}$

Binitetna ikonografija ilustracije Ps 110,1 iz Utrechtskog psaltira ponavljat će se još neko vrijeme u brojnim engleskim, francuskim, normandijskim, pa onda njemačkim i talijanskim psaltirima, primjerice u Ormesbyjevu psaltiru $^{32}$ ili Sidneyskoj Bibliji ${ }^{33}$ i drugima, ali će s vremenom sve češće prelaziti

\footnotetext{
${ }^{29}$ Više o tomu u PEHAR 2016: 11-25; 146-163.

${ }^{30}$ Iako je danas uobičajena, ova je antropomorfnost u prikazu Oca bila na Zapadu gotovo nezamisliva sve do 12 . stoljeća. Na Istoku se tradicija prikaza tri istovjetne muške figure koje sjede na zajedničkom prijestolju može slijediti sve do koptskog umjetničkog kruga čiji su početci još od 6. ili 7. stoljeća. Usp. KANTOROWICZ 1947: 77. Ipak, treba jasno reći da se ni kod ovakvih istočnih prikaza nije radilo o izravnim prikazima Boga Oca i Duha Svetoga, nego o prikazima starozavjetnih alegorijskih ukaza, koji su na Istoku shvaćani kao »slika Pralika u njegovom presliku « (riječi kardinala Joachima Meisnera, prema MIKLISS DE DOLEGA 1996: 9). Tako da o ilustracijama Ps 110,1, koje donose prikaz Boga Oca, slobodno možemo govoriti kao o prvim izravnim antropomorfnim prikazima Boga Oca u kršćanstvu uopće. O zaziranju od antropomorfizma u kršćanskoj slici Boga više u PEHAR 2016: 167-168.

${ }^{31}$ Usp. BÜTTNER 2004: 33.; Usp. HASELOFF 1938: Tafel 6. i 14.

${ }^{32}$ Riječ je o bogato ilustriranom psaltiru iz perioda engleske gotike (kraj 13. i prva polovica 14. stoljeća). Ime je dobio po Robertu von Ormesbyu, prioru katedrale u Norwichu iz toga vremena. Više u LAW-TURNER 2017.

${ }^{33}$ Rukopisna bogato oslikana Biblija, nastala oko 1260-1270. godine, najvjerojatnije u Canterburyu. Čuva se u knjižnici Warburg instituta u Londonu, Sidney Sussex College. MS 96. Ilustracija Ps 110,1 na f. 192r. na stranici: https://iconographic.warburg.sas.ac.uk/vpc/VPC_ search/record.php?record=62730 (19.11.2019.)
} 
u trinitetnu shemu, koja će početkom 12. i u 13. stoljeću na Zapadu i potpuno prevladati. Tako će ilustracija Ps 110,1 utrti put jednom ikonografski potpuno novom prikazu Presvetoga Trojstva.

\subsection{Od biniteta prema trinitetu}

Kako je u teologiji tek značajnim razvojem pneumatologije, odnosno dogmatskim definiranjem božanske časti Duha Svetoga na Prvom carigradskom koncilu (drugom ekumenskom) 381. godine, ${ }^{34} \mathrm{u}$ bitnom dovršeno formiranje kršćanskoga Vjerovanja i zaokružen dogmatski izričaj o trojstvenom Bogu, tako se i u ikonografiji vezanoj za Ps 110,1 tek početkom 12. stoljeća dodavanjem slici Oca i Sina figure goluba kao simboličkog prikaza Duha Svetoga, dovršilo ikonografsko oblikovanje kršćanske slike Boga na koju se odnosilo kršćansko tumačenje ovoga psalma. Likovima Oca i Sina koji su u kontekstu ilustracije Ps 110,1 prikazivani kao sustolnici (suvladari) na nebeskom prijestolju - »synthronoi«, pridodaje se sada simboličan prikaz Duha Svetoga, čime se zaokružuje i dovršava ikonografsko oblikovanje kršćanskog poimanja slike Boga kao Trojstva (Slika 2.). Na tim trinitetnim prikazima Sin sjedi uvijek zdesna Ocu na nebeskom prijestolju, dok Duh Sveti u obličju goluba lebdi između njih najtješnje povezujući obojicu, vrlo često jednim krilom dotičući Oca, a drugim Sina.

Njemački povjesničar umjetnosti Günther Haseloff u svom poznatom popisu zapadnih psaltirskih ilustracija 12. i 13. st. (HASELOFF 1938) jasno pokazuje da je ova trinitetna shema prevladavala u tim stoljećima kao ilustracija Ps 110,1. Kasniji povjesničar umjetnosti i izvrstan poznavatelj trinitarne ikonografije, Wolfgang Brauenfels, drži da zapadna ikonografija Ps 110,1 na ovaj način zapravo nasljeduje jedan stariji niz bizantskih psaltira koji su kao ilustraciju tog psalamskog retka redovito imali trinitetnu shemu, bilo da se radilo o prikazu trojice Abrahamovih posjetitelja (što je zapravo neizravni prikaz otajstva Trojstva kao slika slike Boga, budući da Abraham nije stvarno vidio Boga), kakav je primjerice u Codex Barbarinus iz 11. stoljeća, ili na nekim mjestima o simboličkom prikazu tipa Priprava prijestolja ili Etimasia (grč. $\dot{\tau} \tau o \iota \mu \alpha \sigma i \alpha)^{35}$ okruženom anđelima. ${ }^{36}$

\footnotetext{
${ }^{34}$ Usp. DENZINGER; HÜNERMANN 2002: br. 150-151.

${ }^{35}$ Priprava prijestolja ili Etimasia ikonografski je naziv za prikaz Božjeg prijestolja zajedno s elementima Isusove muke, knjigom života i simbolom goluba. Radi se o jedinstvenoj kombinatorici koja pojedinačne simbole za pojedine božanske osobe ujedinjuje u jedan jedinstven simbolički prikaz Presvetoga Trojstva. Usp. PEHAR 2016: 158.

${ }^{36}$ Usp. BRAUENFELS 1954: XXVII.
} 


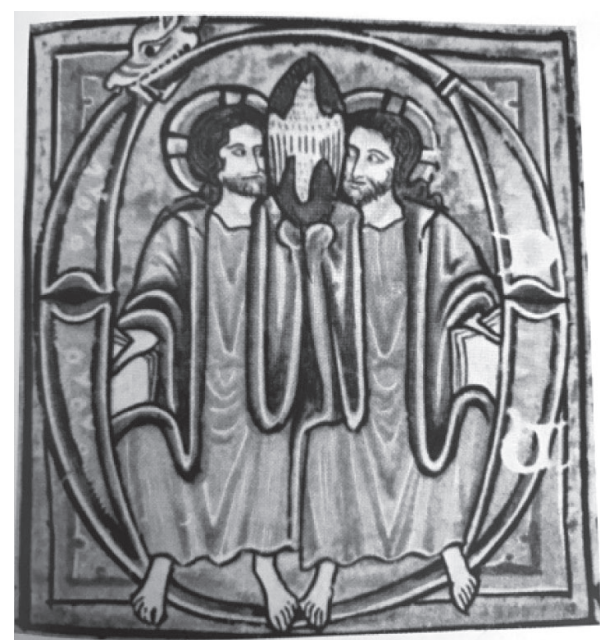

Slika 2. Ilustracija Ps. 110,1, Psaltir u posjedu Sir S. Cockerell iz Cambridga, f. 11r., oko 1240. Izvor: BRAUENFELS, W. 1954. Die Heilige Dreifaltigkeit. Düsseldorf: 23.

Figure 2. Illustration Ps 110,1, Psalter von Sir S. Cockerell in Cambridge, f. 11r., cca. 1240. Source: BRAUENFELS, W. 1954. Die Heilige Dreifaltigkeit. Düsseldorf: 23.

Tako, iako se u rijetkim psaltirima 12. i 13. stoljeća još ponegdje može naći binitetna ilustracija Ps 110,1 , u većini primjera ovoga vremena, poznatog inače kao vrhunac trinitarne ikonografije, prevladavaju trinitetne kompozicije. Trinitetna shema posebno na značaju dobiva s novim zamahom francuske psaltirske ilustracije koji započinje utemeljenjem pariškog sveučilišta 1200. - 1208., a izniman vjetar u leđa postiže sveučilišnim izdanjem tzv. »Pariške Biblije« (prvog značajnog kritičkog izdanja Vulgate) u Parizu 1230. godine koje je sadržavalo i trinitetnu ilustraciju Ps $110,1 .{ }^{37}$ Budući da je ovo sveučilišno izdanje zbog pouzdanosti svoga teksta, po cijeloj Europi bilo znimno cijenjeno, traženo i umnožavano, ${ }^{38}$ tako je brzu izradu novih Biblija i brevijara pratilo i širenje trinitetne sheme ilustracije

\footnotetext{
${ }^{37}$ Prvi razlog ovoga zamaha je u tomu što je Pariška Biblija imala osmodijelnu liturgijsku podjelu psaltira u kojoj je 110. psalam zauzimao istaknut položaj, pa se sukladno tom položaju i ilustraciji prvoga retka istoga psalma pridavala veća važnost. Drugi je razlog sadržajni. Naime, primarnoj nakani ovoga sveučilišnog izdanja morala je odgovarati i ilustracija koja je svojim sadržajem upućivala na znanstveno-teološki sadržaj teksta na koji ukazuje. Usp. HASELOFF 1938: 27-29. 74.

${ }^{38}$ Koliki je bio ugled Pariške Biblije govori primjerice i podatak da je generalni kapitul dominikanskoga reda 1236. donio odluku o zabrani svih drugih biblijskih izdanja osim toga (usp. HASELOFF 1938: 21).
} 
Ps 110,1 , te će se ona proširiti po cijeloj zapadnoj Europi i postati standard ove ilustracije.

Tako primjerice Brauenfels primjećuje da u ovom vremenu čak i kada su se slikari iluminatori trudili ponuditi neku varijaciju postojeće slikovne sheme, u bitnom nisu mogli odstupiti od trinitarne tematike, pa je tako čak i na onim rijetkim ilustracijama koje prikazuju Krista kao središnji lik, uz njega redovito prikaz goluba kao simbola Duha Svetoga i ruke kao simbola Boga Oca da bi tako prikaz Trojstva ostao i sačuvao potpunost. Do te je mjere prvi redak ovoga psalma vezan uz trinitarni sadržaj, da se na nekim njegovim ilustracijama čak pojavljuje i jedan drugi ikonografski tip, kasnije nazvan Prijestolje milosti. Riječ je o antropomorfnom prikazu Boga Oca koji u rukama drži križ s raspetim Sinom, dok između njih lebdi golub kao simbol Duha Svetoga. ${ }^{39}$

Ovaj razvoj pokazuje da je sadržaj Ps 110,1 do 13. stoljeća, kada trinitarna duhovnost i trinitarne pučke pobožnosti dosižu vrhunac, shvaćan isključivo trinitarno, što je konačno i nepovratno odredilo njegovu ilustraciju. Štoviše, od 13. stoljeća, zahvaljujući nastanku prosjačkih redova i snažnom zamahu njihova djelovanja, ova je ilustracija gotovo bez iznimke prikaz Presvetoga Trojstva, pa čak i takav trinitarni prikaz (primjerice Prijestolje milosti) koji se ne referira izravno na sadržaj Ps 110,1 (Kristovo uzdignuće i sjedanje s desna Ocu) ${ }^{40}$ Drugim riječima, slikovno je upućivanje na tekst u potpunosti žrtvovano u korist prikaza kršćanske slike Boga (Trojstvo). Ipak, treba primijetiti kako se na nekim primjerima ilustriranja Ps 110,1 tipom Prijestolje milosti, kao poveznica s psalamskim tekstom u donjem dijelu prikaza pojavljuju i neprijatelji kao podnožje Božjim nogama, što bi makar donekle trebalo upućivati na povezanost s tekstom na koji se ilustracija odnosi. ${ }^{41}$

${ }^{39}$ Usp. BRAUENFELS 1954: XXVII. Više o ikonografskom tipu Prijestolje milosti v. PEHAR 2016: 252-262.

${ }^{40}$ Usp. također BÜTTNER 2004: 33.

${ }^{41}$ Takav je primjerice prikaz tipa Prijestolje milosti kao ilustracija Ps 110,1 u psaltiru koji se čuva u Cambridge Trinity College (MS B.11.4., v. Slika 3.). Usp. BÜTTNER 2004: 33. Na ovom prikazu lice Boga Oca naknadno je premazano, pa se ne vidi. Anđeli drže u rukama sunce i mjesec, a kompoziciji su dodane i dvije augustinske kanonise koje se klanjaju Trojstvu. 


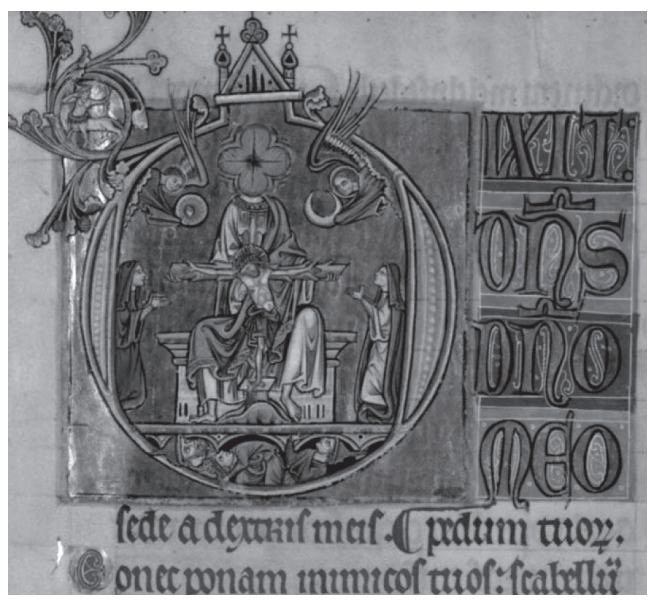

Slika 3. Ilustracija Ps. 110,1, Psaltir iz Cambridge Trinity College, ms. B.11.4., f. 119r, 1250. - 1270. Izvor: https://mss-cat.trin.cam.ac.uk/manuscripts/uv/view.php?n=B.11.4\&n=B.

11.4\#? $\mathrm{c}=0 \& \mathrm{~m}=0 \& \mathrm{~s}=0 \& \mathrm{cv}=132 \& \mathrm{xywh}=2150 \% 2 \mathrm{C}-6 \% 2 \mathrm{C} 2727 \% 2 \mathrm{C} 2212$ (2. 11.2019.)

Figure 3. Illustration Ps 110,1, Psalter von Cambridge Trinity College, ms. B.11.4., f. 119r, 1250-1270. Source: https://mss-cat.trin.cam.ac.uk/manuscripts/uv/view.php?n=B.11.4\&n=B.

$11.4 \# ? \mathrm{c}=0 \& \mathrm{~m}=0 \& \mathrm{~s}=0 \& \mathrm{cv}=132 \& \mathrm{xywh}=2150 \% 2 \mathrm{C}-6 \% 2 \mathrm{C} 2727 \% 2 \mathrm{C} 2212$ (2. 11.2019.)

\section{OD PSALTIRSKE ILUSTRACIJE DO DOMINANTNOG TRINITARNOG TIPA}

Kao što je ranije spomenuto, trinitarna ilustracija Ps 110,1 koja prikazuje Oca i Sina na nebeskom prijestolju s golubom kao simbolom Duha Svetoga kako lebdi između ili iznad njih, poznata kao Psalamsko Trojstvo, ubrzo je nadišla status psaltirske ilustracije i postala značajan (u nekim stoljećima i dominantan) prikaz Presvetoga Trojstva u slikovnosti zapadnog kršćanstva, a kao takav će se zadržati i do danas. Iz psaltira ta će ilustracijska shema prijeći u sva područja kršćanske umjetnosti, te će se afirmirati kao jedan od standardnih zapadnokršćanskih prikaza Trojstva u nebeskoj slavi, osobito obljubljen u vremenu renesanse i baroka, pa s pravom o njemu govorimo kao o zasebnom trinitarnom ikonografskom tipu Trojstvo u slavi.

Već vrlo rano, a u 14. i 15. stoljeću redovito, ilustracije oblikovane na osnovi sheme Psalamsko Trojstvo susrećemo kao uobičajenu trinitarnu ilustraciju (uz ilustracije tipa Prijestolje milosti) u većini liturgijskih knjiga (prije svega misala, antifonara i evanđelistara) i to uglavnom vezano za Isusovu proslavu i uzvišenje, najčešće uz tekstove Credo, Gloria i Te Deum. Kao najstariji primjer takvoga prikaza navodi Brauenfels jedan evanđelistar iz 
ranog 12. stoljeća (Pembroke College, Cambridge). ${ }^{42}$ Vremenom će takav prikaz Trojstva postati dominantan u svim područjima i formama kršćanske umjetnosti, od molitvenika i katekizama, do prenosivih slika, zidnih i stropnih freski i kompozicijski veoma složenih oltarskih pala, pa sve do reljefa i skulptura.

U kompozicijskom smislu ovi trinitarni prikazi vremenom postaju sve bogatiji i složeniji, pa se Trojstvu (u slavi) dodaju likovi anđela i svetaca, a s vremenom i zemaljski likovi papa, vladara, zaštitnika, mecena, tako da se takve slike katkad pretvaraju u raskošne kompozicije prikaza nebeskih i zemaljskih staleža, nerijetko prema Augustinovu djelu De civitate Dei. Ovakve će kompozicije prikazivanja mnoštva nebesnika s Trojstvom u slavi kao središtem i zemnika pogledom usmjerenim prema toj slavi, postati osobito poznate kroz djela velikana poput Rubensa (Sveto Trojstvo i klanjanje obitelji Gonzaga) i Ticijana (Gloria), ali i mnogih drugih. Početkom 16. stoljeća, najprije u Nizozemskoj, a onda po cijeloj Europi, ovaj se ikonografski trinitarni tip Trojstvo u slavi susreće najčešce kao oltarna slika. Štoviše, vremenom se ustalio kao prototip oltarne slike, posebice tijekom renesanse i baroka, ali i stoljećima kasnije. ${ }^{43} \mathrm{Na}$ Zapadu je postao osobito obljubljen kroz prikaze Marijina uznesenja i krunjenja (Slika 4.), osobito aktualne u vrijeme katoličke obnove u vremenu nakon reformacije, ali i kroz prikaze svetaca, zaštitnika crkava ili redova, koje se također vrlo često prikazivalo u njihovoj nebeskoj proslavi. ${ }^{44}$

Zanimljivo je da je sredinom 16. stoljeća ovaj trinitarni tip sa Zapada prenesen i na kršćanski Istok, ponajprije u Grčku, a kasnije i dalje, osobito u Rusiju. U Istočnoj su Crkvi ovi prikazi redovito nazivani Novozavjetno Trojstvo, čime se ističe razlika od prikaza tipa Gostoprimstvo (Gostoljublje) ili Filoksenia (grč. $\varphi \iota \lambda o \xi \varepsilon v i \alpha$ ), tj. alegorijskih prikaza starozavjetne trojice Abrahamovih posjetitelja koji se tumače kao ukaz na Trojstvo. Ipak, na Istoku ova trinitarna ikonografija nije dominirala kao na Zapadu, jer se pravoslavlje - s obzirom da kompozicija uključuje izravan prikaz Boga Oca, što oni drže neprimjerenim - službeno distanciralo od takvih prikaza već na Stokapitelnom saboru 1551. godine, a kasnije i na Svetoj sinodi Carigradske crkve 1776. godine. ${ }^{45}$ Ipak pojedinačni se primjeri mogu susresti i u kasnijim stoljećima.

\footnotetext{
$\overline{42}$ Usp. BRAUENFELS 1954: XXVII. Autor se poziva na »Index of Christian Art « iz Princetona, ali ne navodi signaturu evanđelistara.

${ }^{43}$ Usp. BRAUENFELS 1954: XXXII-XXXV. Također PEHAR 2016: 215-216.

${ }^{44}$ Usp. BRAUENFELS 2015.

${ }^{45}$ Usp. PEHAR 2016: 214-215.
} 


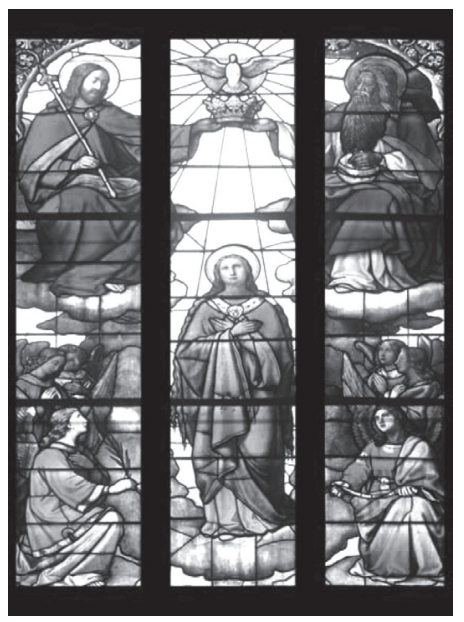

Slika 4. M. Ainmiller, H. M. von Hess, W. von Kaulbach, Presveto Trojstvo kruni Blaženu Djevicu Mariju, detalj vitraja u katedrali Uznesenja Blažene Djevice Marije u Zagrebu, 1843.-1845. Izvor: PEHAR, M. 2016. Otajstvo Trojedinoga Boga u slikovnome izričaju. Zagreb: Kršćanska sadašnjost: 289.

Figure 4. M. Ainmiller, H. M. von Hess, W. von Kaulbach, Holy Trinity crowns the Blessed Virgin Mary, detail of the vitriol in the Cathedral of the Assumption of the Blessed Virgin Mary in Zagreb, 1843-1845. Source: PEHAR, M. 2016. Otajstvo Trojedinoga Boga u slikovnome izričaju. Zagreb: Kršćanska sadašnjost: 289.

\section{ZAKLJUČAK}

Već je na početku rada spomenuto da se u slikovnom prikazivanju Presvetoga Trojstva može razlikovati više ikonografskih tipova (simbolički, alegorijski, antropomorfni i drugi), te je istaknuto kako dominantno mjesto među njima u zapadnoj ikonografiji zauzima tip Trojstvo u slavi. Ovaj se trinitarni ikonografski tip, kako smo pokazali, razvio neposredno iz psaltirske ilustracije prvoga retka 110. psalma, koja slijedeći tipološku egzegezu psaltira i iz nje izvedenu kristologizaciju psaltirskih sadržaja, započinje kao prikaz Kristova uzdignuća u nebesku slavu.

U psaltirskoj ilustraciji za Ps 110,1 u 8. i 9. st., uz Krista se kao glavni nositelj prikaza Sinovljeva uzdignuća u slavu pojavljuje lik Boga Oca i to u ljudskom obličju (u obličju starca). Budući da nisu zabilježeni raniji takvi prikazi prve božanske osobe, ovakve se ilustracije Ps 110,1 s pravom drže najranijim antropomorfnim prikazima Boga Oca. Početkom 12. stoljeća će spomenutom binitetnom prikazu slike Boga vezanom za Ps 110,1 biti pridodan i golub kao simbol Duha Svetoga, a taj novi trinitaran prikaz slike 
Boga kao ilustracija spomenutog psalamskoga teksta poznat je kao Psalamsko Trojstvo.

Kako su psaltirske ilustracije 12. i 13. stoljeća tijekom sljedećih stoljeća poslužile kao predlošci za izradu i drugih knjižnih iluminacija, a uz podršku tipološke egzegeze i kristologizacije psaltira i predlošci za stvaranje kasnijih ikonografskih tipova, tako ce i ova ilustracija Ps 110,1 postati osnova za stvaranje novog ikonografskog tipa prikaza Presvetoga Trojstva nazvanog Trojstvo u slavi. Radi se o prikazu zajedništva triju božanskih osoba u nebeskoj slavi. Likovi se Oca i Sina prikazuju sjedeći na nebeskom prijestolju, najčešće u istoj ili gotovo istoj razini, s prikazom goluba kao simbolom Duha Svetoga, uglavnom između Oca i Sina ili neposredno iznad njih. Ikonografski gledano, možemo razlikovati prikaze na kojima su Otac i Sin prikazani kao identični likovi, čak u potpuno istoj odjeći, od onih na kojima su različiti, te je Otac u obličju starca, a Sin u obličju zemaljskog Isusa muževne dobi.

Zanimljivo je zaključno primijetiti da je s obzirom na rasporedbu likovnih elemenata, Psalamsko Trojstvo (kao i kasnije Trojstvo u slavi) horizontalne kompozicije (za razliku od vertikalne kompozicije većine drugih trinitarnih ikonografskih tipova), što dodatno potvrđuje podrijetlo ove psalamske ilustracije. Budući da ona svoje podrijetlo vuče iz starokršćanskih bizantskih izvora, ne može se zanemariti njezina sličnost s ranijim prikazima trojice identičnih ili sličnih muškaraca bizantskog starokršćanskog tipa Filoksenia (temeljenima na Post 18). Ipak, jasno je da je taj bizantski tip više kompozicijski nego sadržajno utjecao na ikonografsko oblikovanje Psalamskog Trojstva, jer se pod utjecajem izravnoga povezivanja kršćanskoga sadržaja i psalamskih riječi uz koje dolazi, kod psalamske ilustracije primjećuje značajan sadržajni iskorak. Njezin brzi razvoj pokazat će i dodatni sadržajni napredak, te će ona, napuštajući binitetnu i prihvaćajući trinitetnu shemu (dodatkom goluba kao simbola Duha Svetoga), uskoro postati prikaz cjelovite kršćanske slike Boga kao Trojstva. Ovoj će slici ostati vjerna čak i kada ona nema izravnu povezanost s psalamskim riječima (kao što je slučaj kod korištenja tipa Prijestolje milosti za ilustraciju Ps 110,1). Ustrajanjem na trinitarnoj slici Boga u nebeskoj slavi dominirat će tako ova psaltirska ilustracija osobito u mnogim privatnim, za laike uređenim brevijarima 13. i kasnijih stoljeća, ali i prijeći u sva područja zapadne crkvene umjetnosti. Do 15. st., kada trinitarna duhovnost i pobožnost dosižu svoj vrhunac, upravo su prikazi tipa Trojstvo $u$ slavi omiljeni prikazi koji ovu pobožnost osnažuju i pokazuju.

S obzirom na teološki sadržaj ove psalamske ilustracije, u početku se, kako smo vidjeli, radilo o oslikavanju tipološkoga tumačenja Ps 110,1, pri čemu se u kontekstu nikad do kraja završene borbe s arijanizmom ispovije-

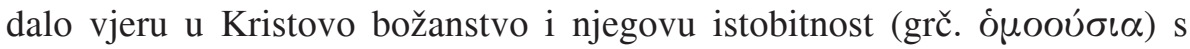


Ocem. Ovomu je trebala služiti i horizontalna postava kompozicije, kojom se dodatno naglašavala jedna božanska bit i ista božanska čast svih triju osoba Presvetoga Trojstva, za razliku od vertikale drugih ikonografskih trinitarnih tipova, koja je mogla upućivati na subordinaciju (hijerarhijsku podređenost Sina Ocu). Tako je uz dogmatski zahtjev za jedinstvom božanske naravi, ilustracija naglašavala i snažnu nutarnju povezanost božanskih osoba, što se pokazuje prostornom blizinom Oca i Sina i suvladarskim sjedenjem na jednom nebeskom prijestolju, ali i znakovitošću pozicije goluba kao simboličkog prikaza Duha Svetoga. On je vrlo često prikazivan tako da najtješnje povezuje tijela ili glave Oca i Sina (iskaz ljubavi Oca i Sina) ili da vrhovima krila povezuje usta Oca i Sina, što se može tumačiti i kao ukaz na Filioque ( $i$ Sina), izraz koji u Vjerovanju Zapadne Crkve označava da temeljem istobitnosti Sina s Ocem, Duh Sveti izlazi od Oca i Sina kao jednoga počela.

Zbog navedenih sadržajnih i kompozicijskih specifičnosti slikovni prikaz na kojemu su Otac i Sin u ljudskom obličju prikazani u sjedećem položaju na zajedničkom nebeskom prijestolju, a Duh Sveti u obličju goluba koji ih povezuje smješten između njih, danas se drži zasebnim trinitarnim ikonografskim tipom koji je uvelike prerastao status psaltirske ilustracije iz koje se razvio. On se s obzirom na teološki sadržaj danas najčešce naziva Trojstvo u slavi, ali s obzirom na podrijetlo i razvoj iz psaltirske ilustracije ostaje trajno poznat i kao Psalamsko Trojstvo. Kao Trojstvo u slavi bit će unutar zapadnoga kršćanstva, a osobito u katoličkim krajevima, u različitim likovnim formama i u svim područjima crkvene umjetnosti obljubljen kroz sva stoljeća sve do najsuvremenijih slikovnih ostvarenja, a pod nazivom Novozavjetno Trojstvo prihvaćen je djelomice i u okviru pravoslavlja, te je unatoč službenim protivljenjima pravoslavne teologije već stoljećima značajno prisutan i na kršćanskom Istoku.

\section{IZVORI}

Bible, Sydney Sussex College, Canterbury 1260-1270, Cambridge, sign. MS 96. URL: https://iconographic.warburg.sas.ac.uk/vpc/VPC_search/record.php?record=62730 (19.11.2019.).

DENZINGER, H.; P. HÜNERMANN (ur.). 2002. Zbirka sažetaka vjerovanja, definicija $i$ izjava o vjeri i ćudoređu. Đakovo: Karitativni fond UPT.

KAŠTELAN, J.; B. DUDA (ur.). 1983. Biblija, Zagreb: Kršćanska sadašnjost.

Psalter, Trinity College Cambridge, sign. B.11.4. URL: https://mss-cat.trin.cam.ac.uk/ manuscripts/uv/view.php?n=B.11.4\#?c=0\&m=0\&s $=0 \& \mathrm{cv}=132 \& \mathrm{xywh}=0 \% 2 \mathrm{C}-$ 365\%2C5453\%2C4424 (19.11.2019.). 
Sidney Sussex College. MS 96. Illustration Ps 110,1 f. 192r. URL: https://iconographic. warburg.sas.ac.uk/vpc/VPC_search/record.php?record=62730 (19.11.2019.).

The Utrecht Psalter, Universiteitsbibliotheek Utrecht, sign. Ms. 32. URL: http://psalter. library.uu.nl/ (19.11.2019.).

\section{LITERATURA}

BRAUENFELS, W. 1954. Die Heilige Dreifaltigkeit. Düsseldorf: Verlag L. Schwann.

BRAUENFELS, W. 2015. Dreifaltigkeit. E. Kirschbaum (ur.) Lexikon der christlichen Ikonographie, Sv. I. Freiburg im Breisgau: Herder, 534-535.

BÜTTNER, F. O. 2004. Der illuminierte Psalter im Westen. F.O. Büttner (ur.). The illuminated Psalter, Studies in the Content, Purpose and Placement of its Images. Turnhout: Brepols, 1-106, 459-479.

CIFRAK, M. 2007. Ps 110 (109) u Poslanici Hebrejima. M. Cifrak i N. Hohnjec (ur.). Neka iz tame svjetlost zasine! Zbornik radova u čast prof. dr. sc. Adalbertu Rebiću povodom 70. obljetnice života i 40. obljetnice profesorskoga rada. Zagreb: Kršćanska sadašnjost, 453-466.

DAUTZENBERG, G. 1995. Psalm 110 im Neuen Testament. G. Dautzenberg (ur.). Studien zur Theologie der Jesustradition. Stuttgarter Biblische Aufsatzbände19. Stuttgart: Katholische Bibelwerk, 63-67.

GRAEVEN, H. 1898. Die Vorlage des Utrechtpsalters. Repertorium für Kunstwissenschaft, 21: 28-36.

HASELOFF, G. 1938. Psalterillustration im 13. Jahrhundert. Studien zur Geschichte der Buchmalerei in England, Frankreich und den Niederlanden. Kiel: Haseloff.

HÄUSSLING, A. A. 2009. Psalmen: VI. Liturgie. W. Kasper (ur.). Lexikon für Theologie und Kirche. Sv. VIII. Freiburg - Basel - Wien: Herder, 696-698.

HOSSFELD, F-L. 2009. Psalmen: I. Altes Testament. W. Kasper (ur.). Lexikon für Theologie und Kirche. Sv. VIII. Freiburg - Basel - Wien. Herder, 689-693.

JÖRG AUF DER MAUR, H. 2009. Psalmen: V. Alte Kirche. W. Kasper (ur.). Lexikon für Theologie und Kirche. Sv. VIII. Freiburg - Basel - Wien: Herder, 695-696.

KANTOROWICZ, E. H. 1947. The Quinity of Winchester. The Art Bulletin June 1947 $(X X I X)$ 2: 73-85.

LAW-TURNER, F. C. E. 2017. The Ormesby Psalter, Patrons and Artists in Medieval East Anglia. Oxford: Bodleian Library.

MIKLISS DE DOLEGA, P. 1996. Ikone und Mysterium. Die geistliche Botschaft der Bilder. Köln: Freundeskreis St. Pantaleon.

PEHAR, M. 2016. Otajstvo Trojedinoga Boga u slikovnome izričaju. Zagreb: Kršćanska sadašnjost.

ZAGORAC, V. 1996. Krist posvetitelj vremena. Liturgijska godina. Štovanje svetaca. Časoslov. Zagreb: Kršćanska sadašnjost. 


\title{
Summary
}

Marija Pehar

\section{»TRINITY OF THE PSALM $\ll-$ THE ORIGIN AND ICONOGRAPHIC-THEOLOGICAL DEVELOPMENT FROM THE ILLUSTRATION OF PSALTER TO THE TRINITARIAN ICONOGRAPHIC TYPE}

\begin{abstract}
Although there is no direct revelation of God's Trinity in the Old Testament, Christians have read the Old Testament texts typologically and have recognized among them the prophetic impute to Jesus Christ and his revelation of God as the Father, the Son and the Holy Spirit. This kind of Christian interpretation is obviously marked also in handwritten illustrations that have followed the Old Testament texts throughout many centuries. This paper presents and investigates that type of illustrations. It concerns the so called »Trinity of the Psalm«, the illustration of the first line of Psalm 110 (109), which as an illustration of the Old Testament text actually reveals the Christian interpretation of that text, i.e. points to the Christological-Trinitarian content as the foundation of Christian faith (christologization of the Psalter). The paper examines the iconographic-theological development of the illustration from binary to triune, i.e. the development of the Triune God in the image of the heavenly glory from the illustration of the Psalter (that reaches its peak in the $13^{\text {th }}$ century) to the dominant Trinitarian iconographic type of the Christian West, especially at the time of the Trident Council and Catholic restoration. The main part of the paper analyzes the quite complex iconographic-theological and foremost Christological and Trinitarian content of the »Trinity of the Psalm«, recognizing in that illustration the first complete description of the Christian image of God as Triune, i.e. the earliest direct anthropomorphic depiction of God the Father.
\end{abstract}

Keywords: Psalm 110 (109), Trinity, Psalter, Iconography

Marija Pehar

Catholic Faculty of Theology

Zagreb (Croatia)

m.marijape@gmail.com 